\title{
Teachers' Views on the Use of Photography in Teaching Arts in Croatian Primary Schools
}

NiNA LICUL ${ }^{1}$

$\approx$ Contemporary art education relies on the use of diverse methods, approaches, art techniques, and technologies. Although photography is part of daily visual communication and gallery exhibitions, there is no structured approach to photography as a medium for learning the arts in Croatian primary schools. The objectives of the quantitative study were to determine art teachers' views on (1) their knowledge about photography, (2) their abilities in using photography in art teaching, (3) obstacles to using photography in art teaching, and (4) the importance of photography in students' visual culture. Regarding the fourth objective, we wanted to examine possible differences in terms of the teachers' gender, age, and length of service. A survey was conducted with 112 teachers who teach arts in 5 th to 8 th grades in 17 Croatian counties. The results of the descriptive statistics were supplemented with a qualitative analysis of the teachers' responses in the questionnaire. The results show that the teachers perceive their knowledge about photography obtained by formal education as average, but they assess their abilities to apply photography in their lessons as slightly better. The main problem, in their view, is a low number of art lessons in the Croatian curriculum. The teachers generally agree that photography is very important in a student's visual culture, regardless of the teachers' gender, age. and years of service. These findings indicate the need to place greater emphasis on photography as an artistic medium in primary school, as it may generate new visual knowledge and artistic skills.

Keywords: art education, art teachers, photography, visual communication 


\section{Pogledi učiteljev na uporabo fotografije pri poučevanju likovne vzgoje $\mathrm{v}$ hrvaških osnovnih šolah}

NiNA LiCUL

$\approx$ Sodobna likovna vzgoja temelji na uporabi različnih metod, pristopov, likovnih tehnik in tehnologij. Čeprav je fotografija del vsakodnevne vizualne komunikacije in razstav $\mathrm{v}$ galerijah, $\mathrm{v}$ hrvaških osnovnih šolah ni strukturiranega pristopa do fotografije kot medija za poučevanje o likovni umetnosti. Cilji kvantitativne raziskave so se nanašali na poglede učiteljev likovne vzgoje glede 1) njihovega znanja o fotografiji; 2) sposobnosti uporabe fotografije pri poučevanju; 3) ovir pri uporabi fotografije pri poučevanju; 4) pomena fotografije pri učencih. Izvedena je bila raziskava med 112 učitelji, ki poučujejo likovno vzgojo od 5 . do 8. razreda v 17 hrvaških okrajih. Izsledki analize opisne statistike so bili dopolnjeni s kvalitativno analizo odgovorov učiteljev v vprašalniku. Rezultati kažejo, da učitelji svoje znanje o fotografiji, pridobljeno s formalnim izobraževanjem, dojemajo kot povprečje, vendar sposobnosti uporabe fotografije pri pouku ocenjujejo kot nekoliko boljše. Po njihovem mnenju je glavni problem majhno število učnih ur likovne vzgoje v hrvaškem učnem načrtu. Učitelji se na splošno strinjajo, da je fotografija zelo pomembna v učenčevem dojemanju vizualnega sveta, ne glede na spol, starost in delovno dobo. Te ugotovitve kažejo na potrebo po večjem poudarku fotografije kot umetniškega medija v osnovni šoli, saj lahko ta ustvari novo vizualno znanje in likovne veščine.

Ključne besede: likovna vzgoja, likovni pedagogi, fotografija, vizualna komunikacija 


\section{Introduction}

It is difficult to imagine life without photography. Photography permeates all aspects of human activity - it is a communication, documentary, scientific, mimetic (Sontag, 2005), aesthetic, creative, and artistic medium. Photographers influence the consciousness of individuals (Bedi \& Varga, 2018), provide evidence of time and space (Peraica, 2010), and shape our ideas (Freund, 1980; Share, 2015).

Technological development has enabled artists to use different media to express their ideas. At the same time, art education must be in constant harmony with the development of art (Tomšič Čerkez, 2014). However, Gadsden (2008) justifiably wonders whether certain forms of art or fields of art are considered less valuable than others and therefore omitted from education programmes. Based on the guidelines for arts education (UNESCO, 2006), photography, with its specific processes and results, is among the areas of art with which students have to be familiarised. Because of its special characteristics, photography allows students to develop specific knowledge and skills that cannot be developed in other fields of art (Eisner, 2002), which themselves are characterised by specific artistic processes and transfers of particular knowledge and skills (Linardić, 2015). Moreover, in the context of photography, Eisner (2002) claims that in artistic expression we tend to search for elements in our environment that we can reproduce. For example, if we use a camera with black-and-white film, we search for shadows, exploring the relationship between light and dark; if we use colour film, we normally search for colours in our environment.

The aims of art education are focused on the holistic development of the child, which involves the development of three important categories of behaviour, based on the so-called Bloom's taxonomy of educational objectives: cognitive, affective, and psychomotoric. The psychomotoric domain in art education refers to the reproduction of knowledge in artistic expression, meaning the creation of practical solutions in art-related tasks (Tacol, 1999). In the process of taking photographs, it is necessary to learn to react to visual inputs in our environment and to possess the relevant knowledge that helps our sensory system complete the activity with a successful photograph (Rand \& Zakia, 2006). The relevant knowledge about photographic procedures can also be used in other areas of art: video, film, animation, graphic design, and web design.

Besides the possibility of psychomotor development, the advantages of photography are shown in the cognitive processes of learning. Photography is a means of the author's visual communication with the environment, and it is unique for its instantaneous and simple conveyance of visual messages. A 
possible way of using the communicative functions of photography in classes is the application of "photolanguage«, which involves understanding and verbalisation of different contents, as well as one's own perceptions of photography, in smaller groups, which facilitates verbal expression (Cooney \& Burton, 1986, as cited in Bessell et al., 2007; Ledinšćak et al., 2017). In this aspect, photography is a teaching method, a prompt for critical thinking and creative associations. Cognitive processes in learning and teaching photography are the result of the understanding of artistic and visual concepts and the creation of visual metaphors and allegories (Beck, 2009), which are accomplished by selecting motifs, frames, and visual language.

The affective domain in teaching photography includes aesthetics, experience, and the interpretation and evaluation of photographs (Rand \& Zakia, 2006). Research conducted by Sharples et al. (2003), which involved 180 children of different ages, indicated the advantages of photography as a medium that enables the development of interpersonal activities. The results of this research indicated that from the perspective of children photographs did not represent only their views of the world around them but also signified an active relationship with their parents, peers, and other contents. Therefore, photography is an adequate means of forming an active and creative relationship with the environment, which is one of the basic objectives of art education.

A form of teaching that includes photography as a medium of artistic expression is affected by different factors: the pedagogic, didactic, and methodological competences of teachers, their personal views of the importance of photography, which affect the level of motivation for including photography in the teaching programme in the first place, and physical and organisational conditions for implementing such programmes. Triacca argues that the use of photographs in teaching art is "a necessity, an opportunity and a challenge for the modern teacher« (2017, p. 1). A teacher can use photography in art classes in many ways. The common practice of art teachers is the use of photography as a printed and digital source of knowledge in teaching the language of art. In this case, photography acts as a mediator in the reproduction of the original reality or an original work of art when there is no possibility of introducing students to the authentic or immediate environment or when there is no opportunity for observing the original work of art. Mobile phones with built-in digital cameras, which are widely available today, open up a range of possibilities of using photography as a medium of artistic expression. In this case, a photograph is an artistic medium, and the camera is a modern teaching tool that replaces a pencil, brush, or clay knife.

In comparison with traditional tools, the use of cameras requires a higher level of knowledge in technical characteristics, but the time needed for 
creating a final work of art is shorter. Therefore, the teacher should have specific photographic competences that provide for a high quality of such classes. Furthermore, the teacher has to be able to convey such specific knowledge to the students and provide the students with the opportunity to gain knowledge through experience (Kolb et al., 2001), meaning through using the method of trial and error.

The fact that photographs are not just something found in our textbooks and digital presentations but also permeate social networks, posters, and advertisements, provides considerable evidence about the importance of photography in education. Nowadays, children use mobile phones with built-in cameras at an early age. Research conducted by Bedi and Varga (2018) demonstrated that high school students recognise the importance of photography in contemporary media. However, there is still not enough structured knowledge about photography-based art teaching in primary schools that would be harmonised with the curricula. Croatia has recently started introducing a new national curriculum, but until the process is fully completed, it is carried out in parallel to the current curriculum. In the old programme for art classes in primary school, specific terms related to photography appear in one teaching unit in the $2^{\text {nd }}$ grade (photography, photographer), and in two in $8^{\text {th }}$ grade (photomontage; digital image and other terms within the area of film, that can also refer to photography) (Ministry of Science, Education and Sports, 2006). In the new curriculum, a camera and a smartphone also appear in the $2^{\text {nd }}$ grade as content for achieving outcomes, but also in the $3^{\text {rd }}-8^{\text {th }}$ grades, »the student uses the technical and expressive possibilities of new media technologies (Ministry of Science and Education, 2019). Newbury (1996) says that photography is a marginalised part of primary and secondary education and that it is mostly treated as part of free time or a subject in higher education. Despite that, photography can give a unique contribution to general education, Newbury argues. Judging from the structure of photography teaching present in current art teaching programmes, the situation is slightly better, but methodically still insufficiently shaped. In higher education, teachers develop their photographic competences in different study programmes, but the specificities of holding art classes that include photography are related to the methodology of teaching photography. Conditions of using specific photographic procedures in teaching also differ. Therefore, it is particularly important to determine if there are any prerequisites for the implementation of high-quality, structured photography teaching in primary school art education.

This research aimed to assess the opinions of primary school art teachers about the use of photography as a medium of expression in art lessons. We 
posed specific research questions: the first three refer to the teachers' opinions about the conditions of using photography in classes, and the fourth question refers to their opinion about the importance of photography in classes:

1. How do teachers perceive the level of their knowledge and competences in photography obtained in formal education? Have they received any informal education in this area, if yes, in what forms?

2. How do teachers perceive their abilities in holding art classes that include photography?

3. In art teachers' opinion, what are the obstacles to using photography in art classes?

4. What is the art teachers' opinion about the importance of photography in art education and do demographic characteristics (age, sex, and years of service) affect their opinion?

\section{Method}

\section{Participants}

The research included 112 art teachers who teach fifth- to eighth-grade students in primary schools in 17 of 22 counties in the Republic of Croatia, of which $87(77.7 \%)$ were women, and 25 (22.3\%) were men. In the 2018/2019 academic year, when this research was conducted, there were 2029 primary schools in Croatia (Croatian Bureau of Statistics, 2019). Because art lessons in the Croatian primary schools are reduced to only one school lesson a week, art teachers usually work at two or three schools, so the number of art teachers is significantly lower than 2029. Therefore, the research encompassed $5.52 \%$ of the primary schools and at least $5.52 \%$ of art teachers in Croatia (the exact number is unknown). The lowest number of participants was in the group of teachers aged 30 and younger, while the other three groups were relatively equally distributed: $33 \%$ of the participants were aged 31 to $40,27.7 \%$ of the participants were aged 41 to 50 and $25 \%$ of the participants were older than 50 . The participants' years of service were also relatively equally distributed: $23.2 \%$ of the participants had up to five years of service, $22.3 \%$ had five to ten years of service. The largest share of the participants, i.e., $31.3 \%$, were in the group with 10 to 20 years of service, while $12.2 \%$ of the participants had more than 20 years of service. 


\section{Instrument}

The questions that we posed for this research formed a larger part of the questionnaire for the assessment of art teachers' opinions about the use of photography in primary school art lessons. The questionnaire was sent to art teachers in an electronic form, through the expert committees of all the examined counties. It was also handed out in printed form at the sessions of the expert committees in Primorje-Gorski Kotar County, Zadar County and Istria County.

The teachers assessed their level of photographic knowledge and competences gained in formal education on a five-point Likert scale ( 1 - insufficient to 5 excellent). Due to filter questions, the participants could either skip or respond to the question on the ways of learning about photography outside formal education. The teachers assessed their own ability to hold classes that include photography on a five-point Likert scale ( 1 - insufficient to 5 - excellent), in 15 specific items that referred to all stages of a school lesson: motivational part of the lesson, the transfer of knowledge, correlation, technique demonstration, introduction of assignment, encouragement of students to do practical work, evaluation and grading. To determine the opinions about obstacles to using photography in art lessons, teachers chose from among 13 listed obstacles, but they could also add a response of their own. The teachers also assessed the importance of photography in art lessons by responding to 17 statements on a five-point Likert scale (1 - I fully disagree to 5 - I fully agree). Finally, the teachers could explain their opinions about the use of photography in art teaching by responding to an open-ended question.

The content validity of the questionnaire was reviewed by three research experts. The objectivity was ensured by using clear and unambiguous instructions for filling out the questionnaire. The reliability of the scales was tested using Cronbach $\alpha$, whose values range from .68 to .97 and offer a satisfactory level of the instrument reliability.

\section{Data analysis}

The data were processed using IBM SPSS Statistics 20 (IBM Corporation, 2016). The level of statistical significance was set at $p<.05$. Quantitative analysis of data was supplemented with a qualitative analysis of responses to the openended question about the use of photography in primary school art classes.

Descriptive data are shown in the form of frequencies $(f)$, percentages $(f(\%))$, arithmetic means $(M)$, and standard deviations $(S D)$. To examine the differences among the normally distributed measures, we used a $t$-test for independent variables (difference in the opinions of men and women about the 
importance of photography in art teaching) or a one-way analysis of variance (differences in the opinion of teachers in terms of age and years of service). In the variables expressed in categories, we used nonparametric tests: the $\chi^{2}$ - test, the Mann-Whitney $U$-test, and the Kruskal-Wallis test. In statistically significant differences, the effect size was expressed using the Cramer's $V$ Coefficient. The data obtained in the responses to the open-ended question were analysed using the open-coding approach (Vogrinc, 2008).

\section{Results}

1. Teachers' self-assessment of knowledge in photography and ways of learning about photography outside formal education

The examined teachers assessed their knowledge in photography gained in formal education as good or very good. The participants' responses to all items ranged from 2 (poor) to 5 (excellent). The average result in the scale measuring knowledge in photography gained in formal education was 3.05 (.92) (Table 1).

Table 1

The respondents' self-assessment of photographic knowledge and competencies gained in formal education

\begin{tabular}{|c|c|}
\hline$N=112$ & $M(S D)$ \\
\hline Knowledge of photographic equipment & $2.61(1.07)$ \\
\hline Knowledge of photo-camera parts & $2.55(1.05)$ \\
\hline Control of auto modes of the camera & $2.93(1.18)$ \\
\hline Control of »manual« settings of the camera & $2.68(1.07)$ \\
\hline Photo editing & $2.85(1.24)$ \\
\hline Understanding of artistic language in photography & $3.53(1.03)$ \\
\hline Knowledge of compositional principles in photography & $3.76(1.15)$ \\
\hline $\begin{array}{l}\text { The ability to convey »message« by means of photogra- } \\
\text { phy }\end{array}$ & 3.64 (1.09) \\
\hline Knowledge of history of photography & $2.91(1.01)$ \\
\hline Total & $3.05(.92)$ \\
\hline
\end{tabular}

Sixty-seven (59.8\%) of the examined teachers learned about photography outside formal education systems. Based on the ways they learned about photography outside their formal education, which are listed in Table 2, we may assume that most of the respondents were learning about photography in informal rather than formal ways. 
Table 2

Frequencies of responses about ways of learning photography outside formal education

\begin{tabular}{|c|c|}
\hline$N=112$ & $f(f \%)$ \\
\hline I have used a camera on my own & $59(52.7)$ \\
\hline I have read literature about photography on my own & $54(48.2)$ \\
\hline I have joined a photo club & $7(6.3)$ \\
\hline I have finished a course in photography & $10(8.9)$ \\
\hline I have been taught by someone who is good at photography & $28(25)$ \\
\hline
\end{tabular}

\section{Teachers' self-assessment of knowledge and skills for holding classes that include photography}

Table 3 shows teachers' self-assessment of knowledge and skills for classes that include photography in relation to specific elements of art lessons in primary schools. The average result in the scale measuring knowledge and competences for holding art lessons that involve photography was 3.50 (.79). The responses for all the domains of knowledge and competences ranged from 2 (poor) to 5 (excellent), while most responses ranged from 3 (good) to 4 (very good).

Table 3

Self-assessment of knowledge and skills required for classes that include photography

\begin{tabular}{|c|c|}
\hline$N=112$ & $M(S D)$ \\
\hline Teaching history of photography & $2.86(1.19)$ \\
\hline The ability to correlate photography with contents of other subjects & $3.55(1.00)$ \\
\hline The ability to correlate photography with phenomena from students' environment & $3.80(.92)$ \\
\hline Motivation of students by using a photo analysis & $3.85(.93)$ \\
\hline Demonstration of photographic technique & $3.03(.97)$ \\
\hline Teaching about visual language of photography & $3.66(1.01)$ \\
\hline Teaching about the principles of composition in photography & $3.83(.95)$ \\
\hline The transfer of knowledge about technical possibility of the camera & $2.85(1.05)$ \\
\hline Teaching about photo editing & $2.92(1.16)$ \\
\hline Announcement of a photographic assignment & $3.60(1.00)$ \\
\hline Encouragement of students to be creative in taking photographs & $3.85(.91)$ \\
\hline Encouragement of students to create meanings in photography & $3.70(.90)$ \\
\hline Encouragement of students to find their own expression in photography & $3.73(.92)$ \\
\hline $\begin{array}{l}\text { Encouragement of students to express emotional reactions while taking photographs } \\
\text { or in contact with a photograph }\end{array}$ & $3.63(.93)$ \\
\hline Evaluation and assessment of photographs & $3.72(.91)$ \\
\hline Total & $3.50(.79)$ \\
\hline
\end{tabular}




\section{Obstacles to holding art lessons that include photography}

Of the most frequently reported obstacles to holding art classes that include the use of photography, as much as $92(82.1 \%)$ of the respondents said there was an »insufficient number of art lessons in the curriculum« (Table 4).

Table 4

Frequencies of responses about obstacles to holding art lessons that include photography

\begin{tabular}{|c|c|c|}
\hline & $N=112$ & $f(f \%)$ \\
\hline \multirow{2}{*}{ Spatial obstacles } & Inadequate classroom size & $11(9.8)$ \\
\hline & Inadequate classroom layout & $16(14.3)$ \\
\hline \multirow{3}{*}{ Material obstacles } & Lack of computers & $57(50.9)$ \\
\hline & Lack of cameras / mobile phones & $65(58)$ \\
\hline & Lack of projectors & $26(23.2)$ \\
\hline \multirow{3}{*}{ Technical obstacles } & No possibility of importing photos into computer & $25(22.3)$ \\
\hline & No possibility of printing photos & $69(61.6)$ \\
\hline & Poor lighting in the classroom & $23(20.5)$ \\
\hline Functional obstacles & Insufficient knowledge and competence of the teacher & $32(28.6)$ \\
\hline \multirow{4}{*}{ Organisational obstacles } & No possibility of holding lessons outside the classroom & $24(21.4)$ \\
\hline & Insufficient number of art lessons in the curriculum & $92(82.1)$ \\
\hline & Limitations in arts curriculum & $55(49.1)$ \\
\hline & Limitations imposed by the school leadership & $13(11.6)$ \\
\hline
\end{tabular}

As for other obstacles to holding art classes that include the use of photography, a respondent mentioned a spatial obstacle (we don't have an art workshop with adequate equipment), while another pointed to organisational flaws (there is no literature and experts who would agree on photographic contents that should be taught).

\section{Perception of the importance of photography in students' visual culture}

Table 5 shows the teachers' opinions on the importance of photography in students' visual culture, based on the statements that were mostly formed in accordance with objectives of art education of the National Curriculum for Primary Schools (Ministry of Science, Education and Sports, 2006) and the Decision on Adopting the Curriculum for Arts in Primary School and the History of Art in the Croatian High Schools (Ministry of Science and Education, 
2019). The examined teachers agree that photography is important in students' visual culture.

Table 5

Teachers' opinions about the importance of photography in students' visual culture

\begin{tabular}{|c|c|}
\hline$N=112$ & $M(S D)$ \\
\hline Photography is one of the most important means of communication today. & $4.43(.68)$ \\
\hline Knowledge of photography is important for students' success in education. & $3.62(.89)$ \\
\hline Photography is suitable for adoption of moral and educational values. & $4.05(.81)$ \\
\hline Understanding of photography is of utmost importance in visual culture of students. & $4.15(.79)$ \\
\hline $\begin{array}{l}\text { Photography is closer to students than traditional fields of art and techniques (draw- } \\
\text { ing, painting, sculpting, printmaking). }\end{array}$ & $3.87(.95)$ \\
\hline $\begin{array}{l}\text { Understanding of visual language in photography is important for the recognition of } \\
\text { advertising deceptions (subliminal messages) in a photo. }\end{array}$ & $4.17(.80)$ \\
\hline $\begin{array}{l}\text { The ability to use photographic tools is a competence that can be important for } \\
\text { further education of students. }\end{array}$ & $3.73(.83)$ \\
\hline $\begin{array}{l}\text { The ability to use photographic tools is a competence that can be important for } \\
\text { employment. }\end{array}$ & $3.74(.86)$ \\
\hline Photography is a neglected area in primary school education. & $4.29(.74)$ \\
\hline Photography encourages an active and creative relationship to the environment. & $4.21(.62)$ \\
\hline $\begin{array}{l}\text { Photography encourages imagination, to the same extent or even to a larger extent } \\
\text { than the traditional areas of art (drawing, painting, sculpting, printmaking). }\end{array}$ & $3.77(.89)$ \\
\hline Photograph taking encourages the development of aesthetic sensitivity. & $4.28(.62)$ \\
\hline Photography encourages development of visual perception. & $4.41(.64)$ \\
\hline Photography encourages interest and care for cultural and natural heritage. & $4.17(.72)$ \\
\hline $\begin{array}{l}\text { Photography correlates with other areas of art: painting, sculpture, architecture, ap- } \\
\text { plied arts and design, new media. }\end{array}$ & $4.39(.66)$ \\
\hline Photography encourages visual, critical and creative thinking. & $4.39(.63)$ \\
\hline $\begin{array}{l}\text { Photography facilitates the expression of thoughts, feelings, experiences, opinions } \\
\text { and values. }\end{array}$ & $4.49(.66)$ \\
\hline Total & $4.13(.51)$ \\
\hline
\end{tabular}

In relation to the presented results, we wanted to examine if sex, age, and years of service affected the teachers' opinions. It turned out that men and women did not significantly differ in the overall result of the questionnaire about the importance of photography in students' visual culture $(t=.97 ; p>$ .05), neither did they differ in other statements.

The examined teachers did not significantly differ in the overall result of the questionnaire about the importance of photography in students' visual 
culture in terms of their age $(F(3.107)=1,19 ; p>.05)$. However, we found a statistically significant difference in the responses to this statement: photography correlates with other areas of art: painting, sculpture, architecture, applied arts and design, new media ( $\chi^{2}=8.28 ; p=.040$; Cramer's $\left.V=.18\right)$. Respondents older than 50 agree with the statement to a much lesser degree than their younger colleagues do.

The results also demonstrated that the examined teachers did not statistically differ in the overall result of the questionnaire about the importance of photography in students' visual culture in terms of their years of service $(F(3.107)=.74 ; p>.05)$, except in the responses to this statement: understanding of photography is of utmost importance in visual culture of students $\left(\chi^{2}=8.25 ; p=\right.$ .041; Cramer's $V=.23$ ). The respondents with five to ten years of service agree with the statement to a much higher degree than their colleagues.

The response to the open-ended question Do you think it would be desirable that students use photography in art lessons at school and why? was given by $96(85.7 \%)$ respondents. Two $(2.1 \%)$ of the responses were irrelevant, while 93 (96.9\%) of the responses were positive: the respondents said it would be desirable that students use photography in art lessons at school. There were no negative responses, while the remaining one response refers to the impossibility of introducing photography in art lessons (Until the problem with insufficient number of lessons is resolved, it is not possible to introduce any novelties).

Since almost all the responses were positive, Table 6 shows eight identified categories that present the advantages of using photography in art lessons.

Table 6

Content categorisation of responses to the question about the advantages of using photography in art lessons

\begin{tabular}{|c|c|c|}
\hline Category & Description & Example \\
\hline $\begin{array}{l}\text { Development of } \\
\text { knowledge and } \\
\text { skills (26) }\end{array}$ & $\begin{array}{l}\text { Learning visual } \\
\text { language, specific } \\
\text { terminology and } \\
\text { techniques }\end{array}$ & $\begin{array}{l}\text { Easier and more suitable acquisition of key terms from } \\
\text { certain topics of teaching. (M, age 41-50, >20 years of } \\
\text { service) } \\
\text { The use of photography in teaching is needed for several } \\
\text { reasons: students learn based on reproductions of } \\
\text { artworks, they are introduced to analogue photography } \\
\text { and the works of renowned world photographers; by } \\
\text { taking photos on their own, students can reflect on } \\
\text { artwork elements and composition (F, age 41-50, 10-20 } \\
\text { years of service) }\end{array}$ \\
\hline
\end{tabular}




\begin{tabular}{|c|c|c|}
\hline Category & Description & Example \\
\hline $\begin{array}{l}\text { Medium charac- } \\
\text { teristics (20) }\end{array}$ & $\begin{array}{l}\text { Closeness, availabil- } \\
\text { ity, omnipresence, } \\
\text { contemporariness, } \\
\text { attractiveness, } \\
\text { applicability and } \\
\text { comprehensibility } \\
\text { of photography, its } \\
\text { simple and diverse } \\
\text { use }\end{array}$ & $\begin{array}{l}\text { It is easy to use thanks to the development of technol- } \\
\text { ogy; it is close and attractive to students (because it is } \\
\text { omnipresent) (F, age } 31-40,5-10 \text { years of service) }\end{array}$ \\
\hline $\begin{array}{l}\text { Creativity devel- } \\
\text { opment (13) }\end{array}$ & $\begin{array}{l}\text { Development of } \\
\text { imagination, differ- } \\
\text { ent perspective of } \\
\text { the environment, } \\
\text { diversity of final } \\
\text { work, new experi- } \\
\text { ence }\end{array}$ & $\begin{array}{l}\text {... think that students' fear of creating a bad photo is less } \\
\text { intense than the fear of doing a bad drawing or painting. } \\
\text { Photography offers them a different perspective in com- } \\
\text { parison to drawing, painting or sculpture, and each new } \\
\text { perspective opens new viewpoints. (F, age: up to 30, up } \\
\text { to } 5 \text { years of service) } \\
\text { I think that learning about photography can be useful } \\
\text { because it can change students' perspective of the } \\
\text { world. (F, age 31-40, 5-10 years of service) }\end{array}$ \\
\hline $\begin{array}{l}\text { Visual communi- } \\
\text { cation (11) }\end{array}$ & $\begin{array}{l}\text { Understanding } \\
\text { and conveying } \\
\text { messages, everyday } \\
\text { communication, } \\
\text { advertising }\end{array}$ & $\begin{array}{l}\text { There should certainly be more of it in teaching, because } \\
\text { it is part of everyday communication, understanding and } \\
\text { the conveying of messages. (F, age }>50,10-20 \text { years of } \\
\text { service) } \\
\text { I think that photography could inspire students to think } \\
\text { about visual problems but also about the topic and the } \\
\text { motif. Moreover, students would learn how to convey a } \\
\text { message to a larger number of people more easily and } \\
\text { inspire them to think. (F, age: up to 30, up to } 5 \text { years of } \\
\text { service) }\end{array}$ \\
\hline $\begin{array}{l}\text { Competence and } \\
\text { competitiveness } \\
\text { (9) }\end{array}$ & $\begin{array}{l}\text { Preparation for } \\
\text { life after finishing } \\
\text { school, develop- } \\
\text { ment of generic and } \\
\text { specific competenc- } \\
\text { es, development of } \\
\text { digitalisation }\end{array}$ & $\begin{array}{l}\text { I think it would be good if students used photography in } \\
\text { art lessons at school, because we live in a digital and vir- } \\
\text { tual age, which will be even more like that in the future } \\
\text { (M, age 31-40, up to } 5 \text { years of service) } \\
\text { Unfortunately, photography is highly neglected, and } \\
\text { many jobs depend on it. (M, age 31-40, 5-10 years of } \\
\text { service) }\end{array}$ \\
\hline Motivation (8) & $\begin{array}{l}\text { Satisfaction with } \\
\text { the resulting } \\
\text { artwork, interest } \\
\text { in solving visual } \\
\text { tasks, inspiration to } \\
\text { make art }\end{array}$ & $\begin{array}{l}\text {...the level of interest and success is high, and the work } \\
\text { can be finished faster than »classic" forms of artworks } \\
\text { (F, age }>50,>20 \text { years of service) } \\
\text { It is a medium that is very close and interesting to stu- } \\
\text { dents, which means the motivation is higher at the very } \\
\text { start (F, age } 41-50,10-20 \text { years of service) }\end{array}$ \\
\hline $\begin{array}{l}\text { Active relation- } \\
\text { ship to the } \\
\text { environment ( } 3 \text { ) }\end{array}$ & $\begin{array}{l}\text { Development of en- } \\
\text { vironment percep- } \\
\text { tion, correlations }\end{array}$ & $\begin{array}{l}\text { It surrounds students in real world; what they do first } \\
\text { is open their social networks and communicate with } \\
\text { photos. So why wouldn't this medium be used when } \\
\text { students have it sin their hands " every day? (F, age >50, } \\
>20 \text { years of service) }\end{array}$ \\
\hline $\begin{array}{l}\text { Self-achievement } \\
\text { (3) }\end{array}$ & $\begin{array}{l}\text { Personal develop- } \\
\text { ment, general } \\
\text { knowledge }\end{array}$ & $\begin{array}{l}\text { It enables personal development and acquisition of gen- } \\
\text { eral knowledge (M, age }>50,>20 \text { years of service) }\end{array}$ \\
\hline
\end{tabular}




\section{Discussion}

Art teachers often have a dichotomous role: the role of transmitting knowledge and skills and the role of artists who also continuously develop their skills and then use them in education. Problems concerning teacher guidance and developing appropriate artistic approaches and strategies remain open (Tomšič Čerkez, 2015). Skill improvement and the personal development of teachers have become a necessity, a condition of survival in the profession, and a guarantee of high quality of educational work. The examined art teachers perceived their knowledge about photography obtained by formal education as good (average), but we must take into consideration the fact that most of them acquired additional knowledge of photography outside their formal education, by reading and exploring camera features on their own, which may indicate two things: there is a need for a higher level of photographic competences gained in formal education, and there is a greater interest in photography. In both cases, we may conclude that it is necessary to enrich the academic knowledge in photography. This is supported by results of the research statements, which show that teachers assess their knowledge of visual and compositional elements in photography as the greatest, while the level of their technical knowledge about cameras and photographic equipment was assessed as lower.

However, teachers perceive their knowledge and competences for holding classes that involve the use of photography as slightly better (very good), which may point to a greater self-confidence of teachers in their own pedagogic rather than area-specific competences. Research conducted by Županić Benić (2017) demonstrated that the self-assessment of competences and the use of competences in teaching art are in a positive correlation, so we may assume that teachers who perceive their photographic competences as better would apply their knowledge and competences in photography-based lessons more successfully, which, in turn, would positively affect the quality of the teaching. Based on the results of the statements, our research confirms the results of the research conducted by Županić Benić (2017): art teachers had the lowest selfassessment in area-specific elements of photography (history of photography, parts of camera, equipment, control of manual settings and photo editing) and, consequently, the application of these elements in classes was also assessed as lower (teaching the history of photography, transfer of knowledge about technical possibilities of the camera, demonstration of photographic techniques and photo editing).

The research results referring to teachers' opinion about obstacles to using photography in classes must be interpreted in the context of the Croatian 
education system, while the perception of the importance of photography in students' visual culture may have broader implications. In a comparative analysis of the position of visual arts education in 12 European countries, Turković (2009) finds that visual arts education has a better position in the other 11 countries than in Croatia and that the quality of contents is higher. The position of visual arts education is manifested in the status of the subject and the number of weekly lessons. A large percentage of art teachers in our research expressed dissatisfaction with the number of art lessons per week/year in the Croatian schools and they see this problem as an obstacle in introducing photography to their teaching. Due to this obstacle, certain art techniques are either underrepresented or completely omitted from art education (Linardić, 2015; Turković, 2009). While considering photography from the perspective of the current plan and programme, we encounter another problem, which is that teachers can devote more time to photography only to the detriment of other fields of art.

Nevertheless, the teachers in our research recognise the importance of photography in students' visual culture, and they largely agree that photography is a neglected area in primary school education. In the research of Bedi and Varga (2018), most of the examined high school students saw photography as important for learning and as something ubiquitous in everyday life. If we consider the art education tasks prescribed by the curriculum, the categories arising from a qualitative analysis of the teachers' responses about the advantages of using photography in classes reflect almost all educational tasks of art education (Ministry of Science and Education, 2019; Ministry of Science, Education and Sports, 2006), with the exception of three related categories: »medium characteristics", "competence and competitiveness", and "self-achievement", which cannot be found in the prescribed tasks but represent an additional value in this area. The teachers mostly observed photography characteristics as general specificities that make photography applicable in all aspects of life. However, photography is also important for its specific features that cannot be compared to the features of other areas of art, for example, technical rules of taking photographs, framing and the effect of light. Owing to these specificities, photography enables the development of competences that are highly valued in the labour market today, competences that become more and more needed for establishing a harmonious development of an individual and the society. Finally, they become more and more needed for successful communication between an individual and the environment. 


\section{Conclusion}

This research illustrates the opinions of teachers about the need and feasibility of using photography in art education. Referring to the first two research questions, the conditions of using photography in classes do exist, they are average, and they can be improved. Photography is undoubtedly a widespread and widely available form of art, but it is poorly or insufficiently structured in the Croatian primary school art education. One of the biggest reasons that photography and some other areas of art are so underrepresented in Croatian education is the fact that there are not enough art lessons in the national curriculum, which has already been shown in our results and in previous research (e.g., Turković, 2009). However, teachers recognise the importance of photography as a medium of art and visual communication, and they consider it an appropriate area for the students' acquisition of visual language.

The obtained results have practical implications, and they may offer guidelines for the improvement of the quality of art education. The research results point to the need for the better training of teachers in the use of photography, in the integration of photography in teaching programmes as well as the need for increasing the number of art lessons in the national curriculum. The data obtained in this research can be used in shaping the teacher training programme according to their needs. Better teacher education in art photography may increase the quality of art teaching and create possibilities for additional art classes in the scope of extracurricular activities or after-school programmes. More systematic teaching of the methodology of photography may be achieved with methodological and didactic materials for teachers and students, which would help increase the quality of photography teaching and learning in arts education.

With all the advantages of this research, we must also take into consideration its limitations. The teachers' photographic knowledge and competences, as well as knowledge and competences in teaching photography, were based on self-assessment. A more objective evaluation would include an analysis of students' opinions and an analysis of experts in art didactics. The other critical limitation is the convenience sample. Even though the questionnaire was sent all over Croatia through the county councils and even though the exact number of art teachers was unknown, we believe that the teacher turnout in certain counties was low. Hence, for a better generalisation of results, we would have to motivate a larger number of teachers to respond to the questionnaire. Future research should explore the effectiveness of using photography in teaching and form guidelines for the teachers. It would also be interesting to examine the 
possible ways of correlating the specificities of artistic photography with other school subjects.

As already mentioned, the objectives of art education are focused on the holistic development of children and their active relationship with the environment. Photography as an artistic medium may allow for the realisation of these objectives and offer some specific aspects of artistic expression. The teachers' awareness of the importance of this medium is a step forward in the development of better art education.

\section{References}

Beck, R. J. (2009). The cultivation of students' metaphoric imagination of peace in a creative photography program. International Journal of Education \& the Arts, 10(18), 1-27.

http://www.ijea.org/v1on18/

Bedi, K., \& Varga, M. (2018). Visual perception and attitudes of students toward the role and importance of photography - students' creative and artistic photographic works through projectbased learning. Media Dialogues. Journal for research of the media and society, 30(11), 5-17. Bessell, A. G., Deese, W. B., \& Medina, A. L. (2007). Photolanguage: How a picture can inspire a thousand words. American Journal of Evaluation, 28(4), 558-569.

https://doi.org/10.1177/1098214007306372

Croatian Bureau of Statistics. (2019). Basic schools - end of 2017/2018 school year and beginning of 2018/2019 school year (8.1.2). https://www.dzs.hr

Eisner, E. (2002). The arts and the creation of mind. Yale University Press.

Freund, G. (1980). Photography \& society. D. R. Godine.

Gadsden, V. L. (2008). The arts and education: Knowledge generation, pedagogy, and the discourse of learning. Review of Research in Education, 32(1), 29-61. https://doi.org/10.3102/o091732X07309691 IBM Corporation. (2016). IBM SPSS Statistics for Macintosh, Version 23.o. IBM Corporation. Kolb, D. A., Boyatzis, R. E., \& Mainemelis, C. (2001). Experiential learning theory: Previous research and new directions. In R. J. Sternberg \& L.-F. Zhang (Eds.), The educational psychology series. Perspectives on thinking, learning, and cognitive styles (pp. 227-247). Lawrence Erlbaum Associates Publishers.

Linardić, L. (2015). Attitudes of primary school pupils about printmaking. Metodički obzori, 10(2015)1(21), 2-11. https://doi.org/10.32728/mo.10.1.2015.01

Ledinšćak, J., Popović, Ž., Bogut, I., \& Užarević, Z. (2017). Fotografiranje kao postupak u nastavi: Priručnik za učitelje i studente učiteljskih i prirodoslovnih studija [Photography as a teaching procedure: A handbook for teachers and students of teacher and science studies]. Sveučilište Josipa Jurja Strossmayera u Osijeku, Fakultet za odgojne i obrazovne znanosti.

Ministry of Science and Education [Ministarstvo znanosti i obrazovanja]. (2019). Odluka o donošenju kurikuluma za nastavni predmet Likovne kulture za osnovne škole i Likovne umjetnosti za gimnazije u 
Republici Hrvatskoj [Decision on adopting the curriculum for arts in primary school and the history of art in the Croatian high schools]. (NN 7/2019).

https://narodne-novine.nn.hr/clanci/sluzbeni/2019_01_7_162.html

Ministry of Science, Education and Sports [Ministarstvo znanosti, obrazovanja i športa]. (2006).

HNOS: Nastavni plan i program za osnovnu školu [Curriculum for primary schools].

Newbury, D. (1996). Photography in schools: Current trends in theory and practice. Journal of Art \& Design Education, 15(1), 17-22.

Peraica, A. (2010). Fotografija kao dokaz [Photography as evidence] (Doctoral dissertation).

Filozofski fakultet u Rijeci.

Rand, G., \& Zakia, R. D. (2006). Teaching photography: Tools for the imaging educator. Taylor \& Francis.

Share, J. (2015). Cameras in classrooms: Photography's pedagogical potential. In D. M. Baylen \& A. D’Alba (Eds.), Essentials of teaching and integrating visual and media literacy (pp. 97-118). Springer. Sharples, M., Davison, L., Thomas, G. V., \& Rudman, P. D. (2003). Children as photographers: An analysis of children's photographic behaviour and intention at three age levels. SAGE Publications, 2(3), 303-330.

Sontag, S. (2005). On Photography. Rosetta Books LLC., Straus \& Giroux.

Tacol, T. (1999). Didaktični pristop k načrtovanju likovnih nalog. Izbrana poglavja iz likovne didaktike [Didactic approach to design art tasks. Selected topics in art didactics]. Debora.

Tomšič Čerkez, B. (2014). Perceptual literacy and the construction of significant meanings within art education. International Journal of Art \& Design Education, 33(2), 272-285.

https://doi.org/10.1111/j.1476-8070.2014.01770.x

Tomšič Čerkez, B. (2015). Teaching and learning through art. Center for Educational Policy Studies Journal, 5(3), 5-9.

Triacca, S. (2017). Teaching and learning with pictures the use of photography in primary schools. Proceedings of the International and Interdisciplinary Conference IMMAGINI? Image and Imagination between Representation, Communication, Education and Psychology, 1(9), 952.

Turković, V. (2009). Arts education in transition: Arts education in the European educational system. Metodika: časopis za teoriju i praksu, 10(18), 152-187.

UNESCO. (2006). RoadMap for arts education. The World Conference on Arts Education: Building Creative Capacities for the $21^{\text {st }}$ Century.

http://www.unesco.org/new/fileadmin/MULTIMEDIA/HQ/CLT/CLT/pdf/Arts_Edu_RoadMap_en.pdf Vogrinc, J. (2008). Kvalitativno raziskovanje na pedagoškem področju [Qualitative research in the pedagogical field]. Pedagoška fakulteta UL.

Županić Benić, M. (2017). Stručne kompetencije učitelja u kurikulu umjetničkih područja. [Teacher competences in the arts curriculum] (Doctoral dissertation). Filozofski fakultet u Zagrebu. 


\section{Biographical note}

NinA LicUl is a teaching assistant in the field of art pedagogy and art education at University of Rijeka, Academy of Applied Arts (Croatia). She is currently doing her $\mathrm{PhD}$ in the scientific field of teacher education in the area of fine arts at the Faculty of Education, University of Ljubljana (Slovenia). Her research interests include teaching and learning in visual arts, photography at school and giftedness in visual arts. 